Integritas 4.4 (Fall 2014), pp. 15-20.

doi: $10.6017 /$ integritas.v4i4p15

\title{
A Third Way: The Catholic University as an Empowering Force for Global Justice Response to Kevin Hughes
}

\author{
Marian K. Díaz
}

This weekend, we have addressed what the Catholic tradition and Catholic universities have to offer in response to various essential needs of our world such as extreme poverty, culture, and non-violence. Now, we turn to the role of Catholic education in "A School of Friendship and Wisdom: The Catholic University as the Space of Global Resistance to Globalization."

I agree with the approach of naming threats and opportunities so that Catholic universities may engage globally in a way that is "as wise as serpents and as gentle as doves"(Mt Io:I6b). (I love this quote so much, because here the serpent catches a break, and we are actually called to imitate this shrewdness!) In addition, Kevin appeals for a ressourcement and looks to the history of the Church itself as a resource for learning so as to offer signposts along the way. I would like to follow Kevin's paper in reverse, providing one idea for Catholic universities that want to proceed by actively addressing global social issues, adding a few more resources to help us think critically about how we engage globally, and then a final word from Kevin and Pope Francis about what I call "a third way" of approaching globalization.

Marian K. Díaz is an assistant professor of practical theology at the Institute of Pastoral Studies at Loyola University Chicago. Prior to her husband's appointment as the U.S. Ambassador to the Holy See, she served as the director of "Companions on a Journey" at the College of Saint Benedict and "Corad: Heart Speaks to Heart" at St. John's University. These initiatives were part of the Programs for Theological Exploration of Vocation, funded by Lilly Endowment, Inc. These grants enabled programming for all university constituencies on the themes of personal and institutional vocation with a special focus on the institutions' joint Catholic and Benedictine mission. Dr. Díaz's theological interests include Scripture and early Church history, discernment of vocation, practical theology, and women in the global Church. 


\section{An Idea}

The Catholic university should lead, from the heart of its identity, as a community that pursues justice. I agree with Kevin's assessment that relationships ad extra need to be small scale and hospitable at heart. But perhaps one university has some idea of how to encourage the development of multiple small-scale endeavors, such that these might express a "change of heart" in the university. After having worked on and learned about various strategic plans at different Catholic colleges and universities, I have been excited by Loyola University Chicago's desire to develop a five-year strategic plan centered on social justice.

The vision document outlines a definition of social justice at Loyola University Chicago that builds on and deepens the concept of justice, paying particular attention to the dignity of human persons, the common good, and the transformation of social structures. It incorporates at least four essential commitments: the necessity of a personal or spiritual transformation; a preference to be with and for the poor and marginalized; the notion of accompaniment or solidarity; and a simultaneous focus on the local and global. ${ }^{1}$

Five strategic areas have been identified and Loyola is in the process of getting feedback from each unit on how they can each support this mission and the objectives. The objectives include:

I. Leveraging university resources to ensure underserved student success

II. Reimagining knowledge to solve complex societal challenges

III. Engaging societal challenges globally

IV. Integrating faith, reason, and justice

V. Building a university community of dialogue and justice

So instead of starting with goals for endowments or new construction or programs, the board has determined that we will be moving forward in this direction. Granted, we are moving forward from a strong financial position, but we are redefining who and what we can be as a university.

\section{A Few Resources}

I fully agree with Kevin that the university has something to offer by way of engaging the other, but I would like us to at least step back and be realistic about our capacities at the global level, especially regarding cultural engagement, and to encourage us to consider this task in light of the possibilities within our universities and our local environments. The research of Dr. Milton Bennett of the Intercultural Developmental Research Center has identified the stages in the movement from ethnocentrism to ethnorelativism along a continuum. The first three stages are referred to as ethnocentric, and they include:

I. denial of any cultural difference, the stage of unseeing or even hostility toward other cultures;

1 Loyola University Chicago, Division of Student Development, "Transformative Justice: A Vision for Loyola University Chicago 2015-2020," September 2014, accessed November 21, 2014. 
2. defense involves the polarization of cultures, either idealizing one's own culture as over and against another, or the reverse, an idealization of another culture while feeling mostly critical toward one's own culture; and

3. minimization involves the generic sense that "everyone's like me" or that most of the elements of one's own culture are universal.

The next three stages bring one into increasingly ethnorelative states.

4. acceptance includes the non-judgmental recognition and acceptance of the viability of other cultures;

5. adaptation includes seeing positive aspects of another culture and the beginnings of behavioral adaptation to another culture, and in this stage one's life begins to change; and

6. The integration stage refers to the acceptance that one's own identity has bicultural or multicultural rootedness. ${ }^{2}$ One can shift easily from functioning in one culture to another. While there are no hard and fast rules for progressing through these stages, in most cases it seems that it takes two to three years to integrate another culture into one's own, and this would involve living within the culture.

At this fully integrated stage, one is considered an insider or family (albeit still with limitations), and the language skills are fluent and impact one's thoughts. The reverse translation to one's native culture becomes a challenge as one strives to explain experiences to persons in the native culture. Our current study abroad program, given its length of a semester or a year, would hopefully get someone through the stages of ethnocentrism to at least level four on Bennett's scale, acceptance of difference, and possibly to the initial stages of adaptation to difference.

At some point, we not only need to consider the limited but valuable experiences of study abroad but also the impact these programs have on our "host countries." As we "export" students to other countries for study or service, how does this affect these locations for better or worse?

Another resource that I propose we consider as we engage others globally would be more complex theories of culture. Kathryn Tanner proposes a relational notion of culture:

On a postmodern understanding, cultural elements may cross boundaries without jeopardizing the distinctiveness of different cultures. What establishes the distinctive identities of cultures in that case is the way in which such common elements are used, how they are handled and transformed. The distinctiveness of cultural identity is therefore not a product of isolation; it is not a matter of a culture's being simply self-generated, pure and unmixed; it is not a matter of

2 Milton J. Bennett, "Towards Ethnorelativism: A Development Model of Intercultural Sensitivity," in Cross-cultural Orientation: New Conceptualizations and Applications, ed. R. Michael Paige (Lanham, MD: University Press of America, 1986), 32. 
"us" vs. "them." Cultural identity becomes, instead, a hybrid, relational

affair, something that lives between as much as within cultures. ${ }^{3}$

Tanner argues that the mixedness of cultures still contains the self-critical aspect of modern notions of culture, but now the "internal diversity of cultures is as much the fulcrum of self-criticism as any external cultural "others." 4 This approach better engages the experiences of immigrants, exiles, and oppressed minority populations- those who push back against culturally colonizing tendencies.

In terms of engaging the other globally, do our students really need immersion experiences abroad? Can our college campuses themselves become immersion experiences? In Brave New Family, G.K. Chesterton writes a long, vivid description of how we pursue exotic trips and wild, exciting experiences merely to escape the street on which we live. Of this person, Chesterton claims,

He says he is fleeing from his street because it is dull; he is lying. He is really fleeing from his street because it is a great deal too exciting. It is exciting because it is exacting. It is exacting because it is alive. ${ }^{5}$

When our students engage in study abroad as travel, they run the risk of encountering the other as objects (even objects of study) that (who) we do not have to engage and do not impact us. In terms of our neighbors, Chesterton argues that precisely our neighbors can force us to expand our horizons, something that we fear and dread. And so, do our students really need to fly across an ocean or to our Southern Hemisphere to find "the other" or do they just need to walk across the hallway or look across the classroom?

Catholic universities, I would say, have very complex cultural and institutional identities that exist betwixt and between. They live con un pie en cada lado, with one foot inside the Church and one foot outside the Church as they straddle Church and society. They negotiate between economic, governmental, and legal requirements as well as ecclesial demands. Our institutions reflect the very cultural complexities which I describe here. How can Catholic universities continue to lead the difficult conversations precisely from these complex and yet very real identities?

\section{A Third Way}

Kevin writes toward the end of his introduction, "we will need to think creatively about different modes of advance, creating alternative paths of relationship among institutions and persons across boundaries." What Kevin calls for is a third way, a new way of proceeding that will require us to forge new paths through this deep, complex forest of globalization. As I read this sentence from Kevin's paper, it immediately brought to mind a phrase used by Cardinal Óscar Rodríguez Maradiaga of Honduras in a talk

3 Kathryn Tanner, Theories of Culture: A New Agenda for Theology (Minneapolis: Fortress Press, 1997), 57-58.

4 Tanner, 58.

5 G.K. Chesterton, The Collected Works of G.K. Chesterton, vol. 1 (San Francisco: Ignatius Press, 1986), 138.

6 See above, p. 2. 
given in April 20I4 at Catholic University of America, and echoed in a recent address by Pope Francis to Popular Movements. In his talk, Cardinal Rodríguez issued a call for a shift in the global economy that will respond to the needs of the poor: "To bring about such change of mindset in economy it needs entrepreneurs practicing solidarity." 7 We need people who think creatively and who risk challenge and difficulty in order to shift economic structures on behalf of the poor. Pope Francis just last week addressed the leaders of Popular Movements in Rome. In this address, he called on these leaders to “rejuvenate our democracies," saying,

The prospect of a world of lasting peace and justice calls us to overcome paternalistic welfarism; it calls us to create new ways of participation that include the Popular Movements and animate local, national and international government structures with that torrent of moral energy that arises from the incorporation of the excluded in the building of a common destiny-and this, with a constructive spirit, without resentment, with love. ${ }^{8}$

The pope calls them to consider a new way and that new way involves the incorporation of the excluded and the discarded in the process of building the human community. This call for structural change expresses a particular understanding of globalization. He describes this new way of proceeding as follows:

Some of you said: this system can no longer be endured. We must change it; we must put human dignity again at the center and on that pillar build the alternative social structures we need. It must be done with courage, but also with intelligence, with tenacity but without fanaticism, with passion but without violence. And among us all, addressing the conflicts without being trapped in them, always seeking to resolve the tensions to reach a higher plane of unity, peace and justice.

His understanding of the third way rests on a thoroughly Latin American theology of encounter, engagement, and accompaniment.

I know that among you there are persons of different religions, jobs, ideas, cultures, countries, continents. Today you are practicing here the culture of encounter, so different from that of xenophobia, discrimination and intolerance,

7 Cardinal Óscar Andrés Rodríguez Maradiaga, SDB, "The Catholic Case Against Libertarianism," Keynote Address, proceedings of Erroneous Autonomy: The Catholic Case Against Libertarianism, Catholic University of America, Institute for Policy Research \& Catholic Studies, Washington, DC, June 3, 2014, online at http://whispersintheloggia.blogspot.com/2014/06/the-perspective-of-gospelin-francis.html, accessed February 18, 2015.

8 "Pope's Address to Popular Movements," National Catholic Reporter, October 29, 2014, accessed November 21, 2014, www.zenit.org/en/articles/pope-s-address-to-popular-movements. The pope spoke on October 29, 2014, to participants in the World Meeting of Popular Movements, organized and promoted by the Pontifical Council for Justice and Peace in collaboration with the Pontifical Academy of Social Sciences and with the directors of several movements. 
which we witness so often. Among the excluded there is that encounter of cultures where the whole does not cancel the particularity.

Here I see Pope Francis beginning to forge ahead showing us a third way between fight or flight, a way that encourages creative, engaged, urgent, and intelligent responses to the needs of our indifferent, sick, disposable world. And most importantly, that this third way requires the active participation of the poor and the marginalized in the work of clearing the path. Pope Francis has only one fear: "I fear that these words too may give rise to commentary or discussion with no real practical effect." 9 Who could better alleviate the pope's fears and be a leader in meeting these needs than universities, and in particular, Catholic universities worldwide?

9 Pope Francis, Evangelii Gaudium, at www.vatican.va/evangelii-gaudium/en/. 